\title{
AKTIVITAS ANTIOKSIDAN EKSTRAK KULIT GARCINIA MANGOSTANA L. PADA VARIASI SUHU PENGERINGAN
}

\author{
Annisa Fauzana $^{1^{*}}$, Rohmawati $^{2}$, Muhammad Azhari Herli ${ }^{3}$ \\ ${ }^{* 1}$ Departemen Kimia Farmasi, Fakultas Farmasi, Universitas Andalas, Indonesia, \\ ${ }^{2}$ Prodi D III Anafarma, Universitas Abdurrab, Indonesia \\ ${ }^{3}$ Prodi Sarjana Farmasi, Universitas Muhammadiyah Riau, Indonesia \\ annisafauzana@phar.unand.ac.id
}

\begin{abstract}
Garcinia mangostana (GM) rind contains antioxidant compound that can inhibit free radical activity. There is a significant relationship between heating and antioxidant activity of plants, because of the effect on its antioxidant bioactive compounds composition. This research aimed to identify the relationship between drying temperature of GM rind and its antioxidant activity. The drying was conducted in 72 hours at temperature of 30,60 , and $90^{\circ} \mathrm{C}$. The antioxidant activity was determined using DPPH test method and the result was analyzed using two-way ANOVA method. The result shows that the drying temperature influences the antioxidant activity of GM rind significantly ( $\mathrm{p}<0.05$ ). The drying temperature of $30^{\circ} \mathrm{C}$ variable gave the highest antioxidant activity with $\mathrm{IC}_{50}$ of $20.34927 \mu \mathrm{g} / \mathrm{mL}$.
\end{abstract}

Keywords: Garcinia mangostana, garcinia rind, heating, drying, antioxidant

\begin{abstract}
ABSTRAK
Kulit buah G. Mangostana kaya akan senyawa antioksidan yang dapat menghambat radikal bebas. Terdapat hubungan antara pemanasan dan aktivitas antioksidan suatu bahan alam, dikarenakan pengaruhnya terhadap komposisi senyawa bioaktif antioksidan. Tujuan penelitian ini adalah untuk melihat pengaruh suhu pengeringan terhadap aktivitas antioksidan kulit buah G. Mangostana. Pengeringan dilakukan pada suhu 30,60 dan $90^{\circ} \mathrm{C}$ selama 72 jam. Pengukuran aktivitas antioksidan dilakukan dengan metode DPPH dan hasil pengamatan dianalisis menggunakan ANOVA dua arah. Hasil penelitian menunjukkan bahwa suhu pengeringan berpengaruh nyata terhadap aktivitas antioksidan kulit buah G. Mangostana $(\mathrm{P}<0,05)$. Kulit buah G. Mangostana perlakuan terbaik adalah pengeringan pada suhu $30^{\circ} \mathrm{C}$. Dengan nilai $\mathrm{IC}_{50} 20,349 \mu \mathrm{g} / \mathrm{mL}$.
\end{abstract}

Kata kunci: Garcinia mangostana, kulit buah manggis, pengeringan, pemanasan, antioksidan

\section{PENDAHULUAN}

Produk bahan alam dan antioksidan alami menjadi semakin populer pada dunia pengobatan (Gondokesumo, dkk., 2019). Manggis (Garcinia mangostana L.) merupakan salah satu tanaman yang tumbuh di Indonesia yang diketahui memberikan manfaat bagi kesehatan, yang salah satu bagian terpenting dari manggis adalah kulit buah manggis (KBM) yang dilaporkan mengandung senyawa fenolik seperti tannin, flavonoid, xanthone (Rohman, dkk., 2019) dan senyawa lain, seperti pektin yang bertanggung jawab terhadap aktivitas farmakologi yang diberikannya (Wathoni, dkk., 2019). 
Terdapat beberapa aktivitas farmakologi KBM yang telah tercatat, seperti antioksidan, anti-tumor, anti-alergi, anti-inflamasi, antibakteri, anti-jamur, anti-virus (Meilina dan Hasanah., 2018), renoprotektif (Ansori, dkk., 2019) neuroprotektif, hipoglikemia, dan anti-obesitas. Beragamnya aktivitas farmakologi yang diberikan KBM menunjukkan aktivitasnya terhadap berbagai jalur patologi, sehingga menjadikan KBM menjadi salah satu target yang potensial untuk pengembangan obat (Ovalle-Magallanes, dkk., 2017).

Terdapat beberapa hal yang memengaruhi kandungan bioaktif total dan aktivitas antioksidan suatu bahan alam, diantaranya adalah waktu panen, penggunaan pelarut pengekstraksi, metode ekstraksi, dan perlakuan bahan, seperti pemanasan. Penggunaan pemanasan pada bahan alam diketahui dapat memengaruhi kandungan metabolit sekunder yang berperan pada aktivitas farmakologisnya. Beberapa senyawa dinyatakan rentan terhadap pemanasan, sedangkan penelitian lain menyatakan bahwa proses pemanasan dapat meningkatkan aktivitas biologis berbagai makanan, karena terjadinya perubahan kimia selama pemanasan (Kim, dkk., 2019), salah satunya adalah senyawa antioksidan.

Antioksidan sensitif terhadap cahaya dan panas, oleh karena itu penanganan bahan baku sumber antioksidan harus baik dan dihindarkan dari berbagai faktor yang dapat menurunkan aktivitasnya. Bahan baku segar umumnya berpotensi memberikan aktivitas antioksidan yang tinggi, namun bahan baku segar relatif lebih cepat rusak dibandingkan dalam bentuk kering (Husni, dkk., 2014). Kebanyakan senyawa antioksidan fenolik dalam tumbuhan berikatan kovalen dengan polimer yang tidak mudah larut, sehingga dibutuhkan suatu proses yang efektif untuk memisahkan ikatan tersebut untuk mengaktivasi antioksidan alami dengan berat molekul rendah (Jeong, dkk., 2004).

Flavonoid, yang merupakan salah satu senyawa fenolik, stabilitas dan aktivitas biologinya sangat dipengaruhi oleh pemanasan. Bagaimana perilaku suatu flavonoid terhadap pemanasan, sensitif atau tidak, tergantung pada struktur senyawa tersebut. Beberapa flavonoid lebih tahan terhadap pemanasan, sedangkan beberapa lainnya dapat terdegradasi dengan mudah, sehingga menurunkan aktivitas antioksidan suatu bahan alam (Chaaban, dkk., 2017). Untuk mengoptimalkan kandungan senyawa dan aktivitas antioksidan dari KBM, maka diperlukan pemahaman mengenai perlakuan bahan baku KBM yang baik. Penelitian ini bertujuan untuk menentukan pengaruh pemanasan terhadap aktivitas antioksidan KBM.

\section{METODE}

\section{ALAT DAN BAHAN}

Penyiapan sampel kulit buah G. mangostana

Sampel KBM dipisahkan, dicuci bersih dan dikeringkan. Sampel kemudian dibagi dalam tiga kelompok dan dikeringkan di dalam oven pada suhu $30^{\circ} \mathrm{C}, 60^{\circ} \mathrm{C}, 90^{\circ} \mathrm{C}$ selama 3 hari. Sampel yang telah kering dirajang dan diserbukkan (Kiromah, dkk., 2020). Sebanyak 5 gram serbuk dimaserasi menggunakan etanol $80 \%$ selama tiga hari dan dihomogenkan pada penangas ultrasonik selama 30 menit. Ekstrak selanjutnya disaring dan dikentalkan.

\section{Penentuan aktivitas antioksidan dengan metode 2,2-diphenyl-1-picrylhidrazyl (DPPH)}

Aktivitas antioksidan ditentukan menggunakan alat microplate reader dengan sumuran 96 sebagai wadah sampel. Ke dalam sumuran yang berisikan masing-masing $50 \mu \mathrm{L}$ ekstrak KBM konsentrasi 3,$125 ; 6,25 ; 12,5 ; 25 ; 50$ dan $100 \mu \mathrm{g} / \mathrm{ml}$ dalam metanol dimasukkan $50 \mu \mathrm{L}$ DPPH $80 \mu \mathrm{g} / \mathrm{ml}$. Sumuran kemudian diinkubasi selama 30 menit, untuk selanjutnya dianalisis menggunakan pada panjang gelombang $520 \mathrm{~nm}$. Semua perlakuan dilakukan dengan tiga kali pengulangan (Irivibulkovit, dkk, 2018). Aktivitas antioksidan dihitung menggunakan nilai $\mathrm{IC}_{50}$ masing-masing perlakuan dibandingkan terhadap vitamin $\mathrm{C}$ sebagai kontrol positif.

\section{HASIL DAN PEMBAHASAN}

\section{Pengaruh pemanasan terhadap aktivitas antioksidan ekstrak kulit buah G. mangostana}

Terdapat pengaruh yang signifikan antara suhu pengeringan, konsentrasi larutan uji dan aktivitas antioksidan ekstrak KBM $(\mathrm{P}<0.05)$. Didapatkan nilai $\mathrm{IC}_{50}$ untuk vitamin $\mathrm{C}, \mathrm{KBM}$ tanpa pengeringan dan $\mathrm{KBM}$ dengan pengeringan suhu 30,60 , dan $90^{\circ} \mathrm{C}$ adalah 7.2849 ; 42.3489; dan 20.3492; 91.649; dan $150.938 \mu \mathrm{g} / \mathrm{ml}$ (Gambar 1). Terjadi peningkatan nilai $\mathrm{IC}_{50}$ dengan peningkatan suhu pengeringan 
yang dilakukan, yang dapat dinyatakan dengan meningkatnya aktivitas radikal karena terjadi penurunan aktivitas antioksidan sampel. Kebalikan, peningkatan konsentrasi uji pada masing-masing kelompok suhu pengeringan dapat meningkatkan aktivitas antioksidan bahan, yang ditandai dengan penurunan nilai $\mathrm{IC}_{50}(\mathrm{P}<0,05)($ Gambar 2).

Komposisi fitokimia suatu tumbuhan berperan terhadap aktivitas farmakologisnya. Konsumsi tumbuhan yang kaya akan senyawa metabolit sekunder tertentu bermanfaat untuk kesehatan karena kemungkinan efek antioksidan yang diberikannya. Sebanyak 68 jenis xanthone telah diidentifikasi terdapat pada KBM (Ovalle-Magallanes, Eugenio-Pérez dan Pedraza-Chaverri, 2017), di mana $\alpha-$ mangostin, $\beta$-mangostin, and $\gamma$-mangostin adalah jenis xanthone dengan konsentrasi paling tinggi (Rohman, dkk, 2019). Xanthone, yang merupakan golongan polifenol, merupakan salah satu golongan senyawa pada KBM yang berperan terhadap efek farmakologinya, seperti efek antioksidan (Meilina dan Hasanah, 2018). Senyawa dengan efek antioksidan berperan dengan menghambat auto-oksidasi yang akhirnya akan menurunkan stres oksidatif dengan menurunkan jumlah radikal bebas atau dengan mengoptimalkan pertahanan tubuh melalui peningkatan jumlah antioksidan. Selain itu, antioksidan juga melindungi jaringan dari kerusakan akibat reaksi oksidasi (Ansori, dkk., 2019).

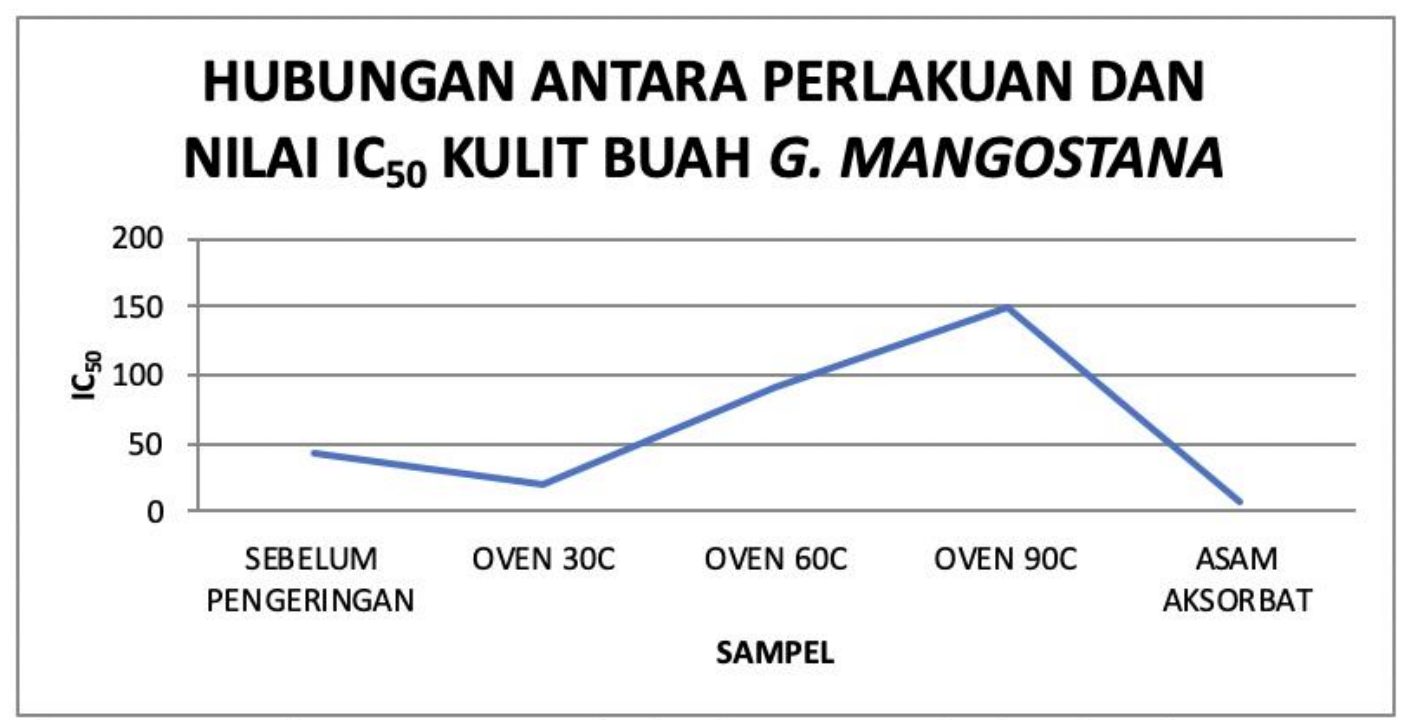

Gambar 1. Pengaruh pengeringan terhadap aktivitas antioksidan ekstrak G. mangostana

Salah satu peran senyawa antioksidan KBM pada efek penanganan stres oksidatif adalah penurunan kadar glukosa darah. Pada pengujian pra klinik, KBM dilaporkan dapat menurunkan kadar gula darah mencit yang diinduksi oleh aloksan. Efek hipoglikemia ini kemungkinan disebabkan oleh perbaikan sel beta pankreas setelah pemberian ekstrak etanol KBM, di mana ekstrak etanol KBM memberikan peredaman senyawa radikal sebesar 72,93 persen (Maliangkay dan Rumondor, 2018). Keadaan stres oksidatif pada kondisi hiperglikemia mengakibatkan peningkatan metabolisme glukosa melalui jalur polyol, peningkatan formasi produk akhir glikasi lanjut, aktivasi protein kinase C, dan peningkatan transfer kelebihan glukosa melalui jalur heksosamin (Ansori, dkk., 2019). Selain senyawa polifenol, seperti xanthone dan flavonoid, aktivitas antioksidan KBM juga disebabkan oleh kandungan pektinnya. Senyawa ini, yang merupakan polisakarida alami, diekstrak dari KBM dalam bentuk serbuk kecokelatan dan tidak berbau, dan memberikan aktivitas hambatan terhadap DPPH dengan $\mathrm{IC}_{50}$ sebesar 161,94 ppm (Wathoni, dkk., 2019).

Xanthone, $\alpha$ - dan $\gamma$-mangostin, dalam jumlah cukup melalui sifat antioksidan dan antiinflamasinya mampu memengaruhi beberapa ekspresi gen tertentu. Kedua $\alpha$ - dan $\gamma$-mangostin dilaporkan dapat menurunkan ekspresi gen PPAR $\gamma$ yang diinduksi LPS dan ekspresi gen inflamasi seperti TNF- $\alpha$, IL-6 dan INF- $\gamma$. Kedua senyawa ini juga dapat menurunkan MAPK dan AP-1, tetapi hanya $\gamma$-mangostin yang dapat menurunkan NF-kB pada makrofage dan adiposit, dan resistensi insulin pada adiposit. Selain itu, senyawa ini dilaporkan dapat menurunkan pelepasan PGE2, COX-2 dan ekspresi iNOS, pelepasan NO dan modulasi TNF- $\alpha$ dan pelepasan IL-4 pada sel makrofage yang 
diinduksi LPS secara in-vitro. Faktor antioksidan dan anti-inflamasi pada KBM diketahui dapat melemahkan progres berbagai penyakit dan mampu memodifikasi progres tersebut melalui jalur metabolisme tertentu (Tousian Shandiz, dkk., 2017).

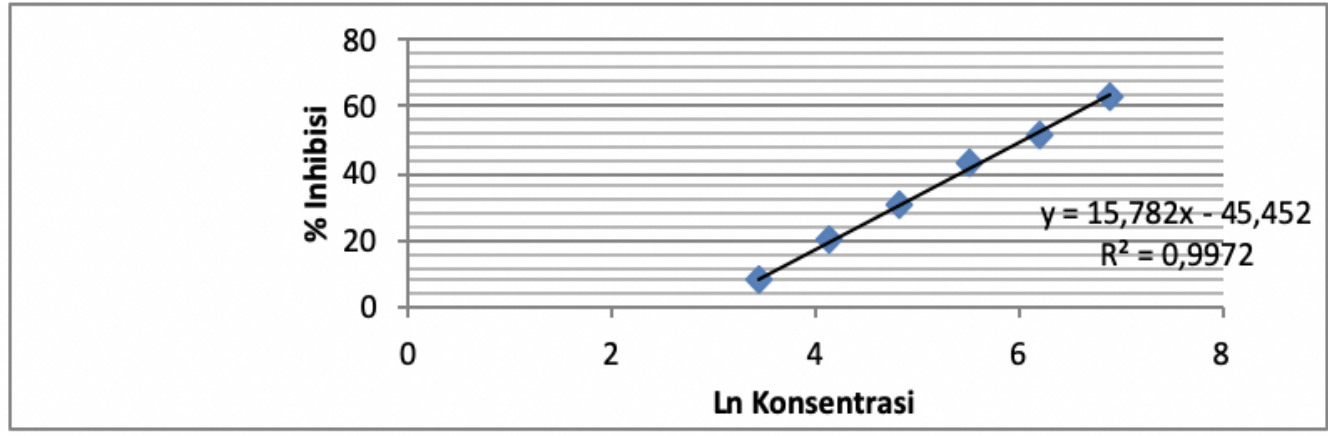

(A)

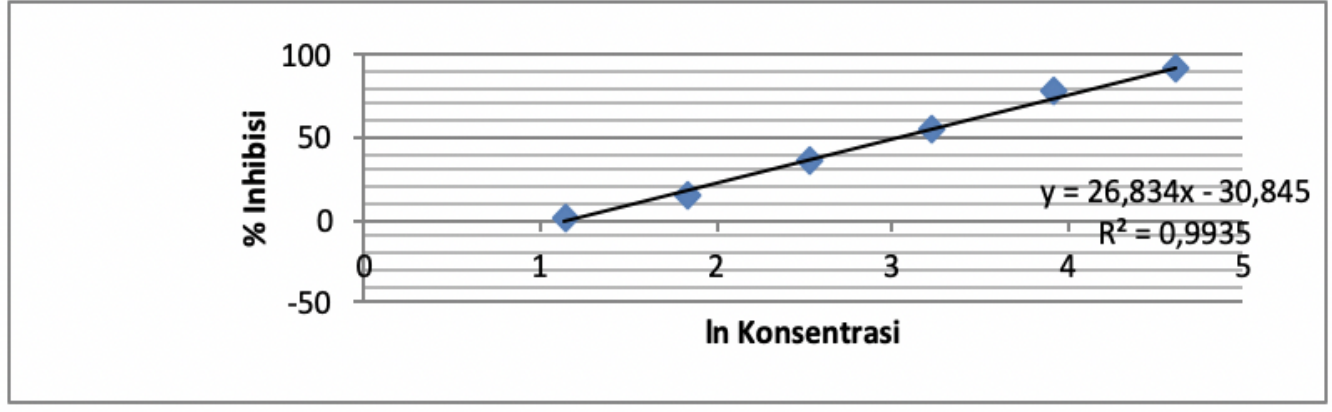

(B)

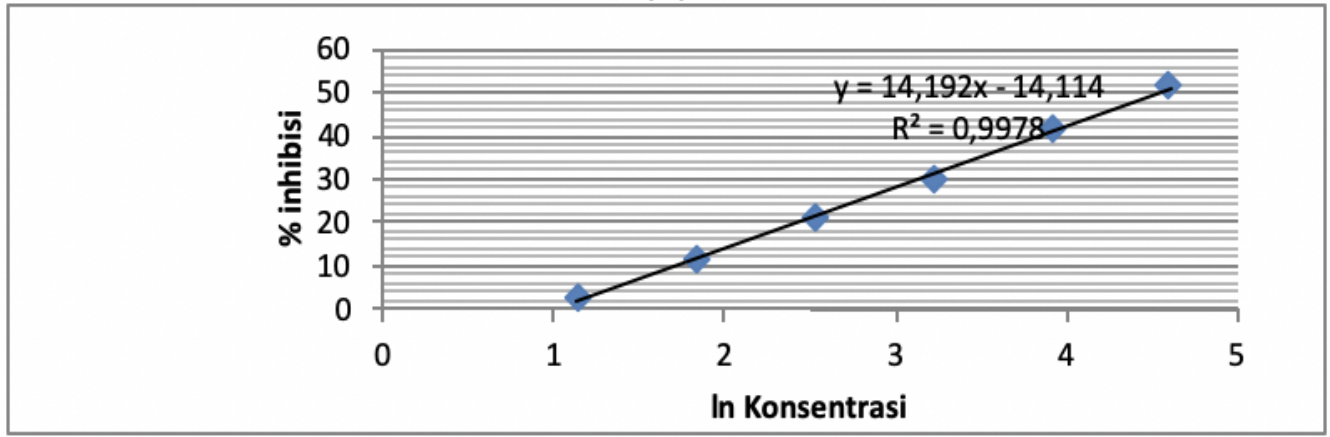

(C)

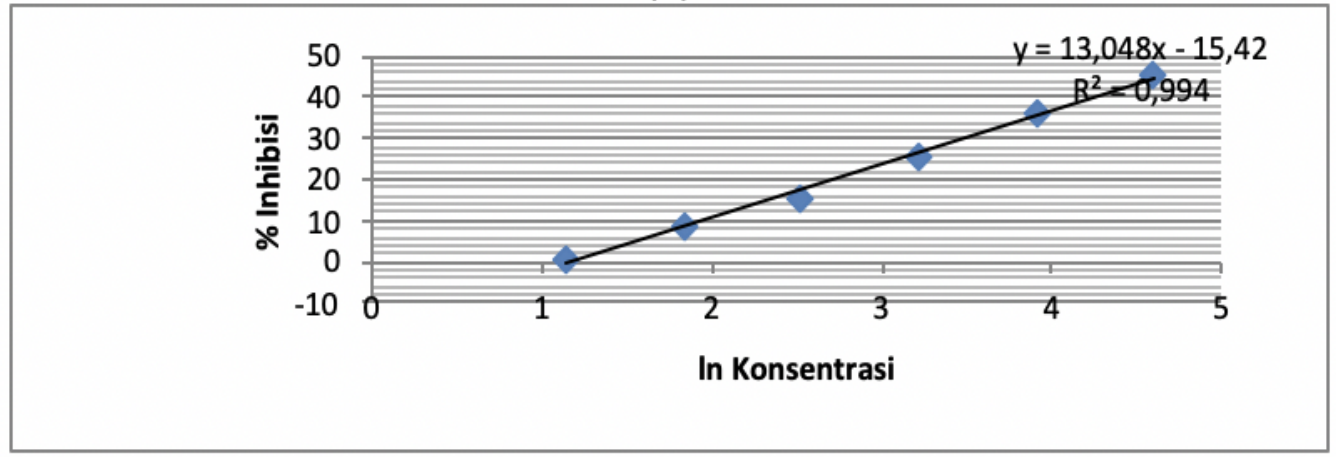

(D)

Gambar 2. Pengaruh linear antara konsentrasi ekstrak dengan aktivitas antioksidan pada masing-masing kelompok perlakuan pemanasan, di mana (A) tanpa pemanasan, (B) suhu $30^{\circ} \mathrm{C}$, (C) suhu $60^{\circ} \mathrm{C}$, (D) $90^{\circ} \mathrm{C}$ 
Penelitian lain, menyatakan bahwa ekstrak etanol KBM memberikan efek nefroprotektif dan dapat menurunkan pengaruh senyawa nefrotoksik akibat paparan asetat terhadap ginjal melalui aktivitas antioksidannya. Aktivitas ini kemungkinan disebabkan oleh kandungan $\alpha$-mangostin yang memperlihatkan efek signifikan dalam menurunkan stres oksidatif. Selain itu, $\alpha$-mangostin juga diketahui memberikan efek nefroprotektif pada pemberian cisplatin yang diketahui berefek toksik terhadap ginjal (Ansori, dkk., 2019). Selain $\alpha$-mangostin, kandungan lain yang diduga dapat mempengaruhi efek perbaikan glomerulus dan tubulus ginjal adalah flavonoid, saponin, dan triterpenoid (Molaei, dkk., 2021).

Pemanasan, waktu panen, penggunaan pelarut dan metode ekstraksi merupakan beberapa faktor yang dapat memengaruhi kadar kandungan kimia dan aktivitas antioksidan KBM. Kadar senyawa bioaktif total dan aktivitas antioksidan pada KBM akan berbeda pada setiap tingkatan kematangan buah. Semakin matang buah manggis diketahui memiliki kandungan senyawa $\gamma$-mangostin, garcinone-E, gartanin, dan smeathxanthone-A yang semakin tinggi yang berpengaruh pada aktivitas antioksidannya. Pada tingkat kematangan buah yang tinggi, didapatkan aktivitas radikal bebas yang semakin rendah, secara in-vitro, menandakan adanya peningkatan aktivitas antioksidannya (Gondokesumo, dkk., 2019). Perbedaan pelarut pengekstraksi juga dapat memengaruhi kandungan senyawa bioaktif dan aktivitas antioksidan KBM. Diketahui penggunaan etil asetat sebagai pelarut akan memberikan kadar polifenol total dan xanthone yang semakin tinggi. Hasil ini berlawanan jika menggunakan air sebagai pelarut. Kadar kandungan bioaktif ini diikuti dengan aktivitas antioksidannya, di mana ekstrak etil asetat $\mathrm{KBM}$ memberikan nilai $\mathrm{IC}_{50}$ paling rendah dengan aktivitas radikal bebas yang semakin rendah (Krisanti, dkk., 2021). Penelitian lain menyebutkan bahwa toluen merupakan pelarut yang paling efisien untuk mengekstrak buah manggis dibandingkan etanol 75\% dan metanol (Mohammad, dkk., 2019).

Pada penelitian ini, terdapat beberapa kemungkinan yang memengaruhi penurunan aktivitas antioksidan ekstrak KBM dengan meningkatnya suhu pengeringan. Pemberian perlakuan pemanasan pada beberapa bahan alam akan memengaruhi kandungan bioaktif yang berefek pada aktivitas antioksidan bahan tersebut. Pemanasan pada beberapa bahan alam dapat meningkatkan aktivitas antioksidan dan pada beberapa bahan lain dapat menurunkan, tergantung pada kandungan golongan senyawa aktif yang berperan (Kim, dkk., 2019). Aktivitas antioksidan sangat dipengaruhi pada perlakuan pemanasan yang diberikan pada bahan. Beberapa senyawa fenol dengan berat molekul rendah dapat terbentuk akibat penguraian setelah pemberian pemanasan hingga $150^{\circ} \mathrm{C}$ yang dapat meningkatkan aktivitas antioksidan suatu bahan alam (Jeong, dkk., 2004).

Senyawa flavonoid, yang menjadi salah satu kandungan KBM, memberikan aktivitas antioksidan tergantung pada strukturnya. Modifikasi seperti alkilasi atau glikosilasi dapat memicu perubahan sifat flavonoid, yang pada akhirnya dapat meningkatkan atau menurunkan aktivitas antioksidan sesuai dengan modifikasinya. Suatu penelitian menyatakan bahwa golongan flavonoid glikosilat lebih tahan terhadap pemanasan dibandingkan dengan flavonoid aglikon, di mana golongan ini memperlihatkan penguraian yang tajam dengan pemberian suhu di atas $90^{\circ} \mathrm{C}$ selama beberapa jam (Chaaban, dkk., 2017). Sama halnya dengan flavonoid, senyawa golongan xanthone juga cukup rentan terhadap pemanasan dalam bentuk larutan dalam airnya. Xanthone akan terurai mengikuti reaksi kinetika orde pertama di mana semakin tinggi suhu pemanasan, degradasi senyawa juga semakin meningkat. Akan tetapi xanthone di dalam bahan alam lebih tahan terhadap pemanasan dibandingkan dalam bentuk larutan airnya. Hal ini disebabkan ikatan xanthone dengan polimer sukar larut di alam yang mencegah degradasi xanthone hingga level tertentu (Beelders, dkk., 2017).

\section{Kesimpulan}

Aktivitas antioksidan ekstrak KBM dipengaruhi oleh perlakuan suhu pengeringan yang diberikan secara signifikan. Peningkatan suhu pengeringan selama tiga hari dapat menurunkan aktivitas antioksidan sampel yang ditandai dengan peningkatan nilai $\mathrm{IC}_{50}$. Selain itu, terdapat hubungan linear antara konsentrasi ekstrak KBM dengan aktivitas antioksidannya, yang menyatakan bahwa peningkatan konsentrasi akan meningkatkan aktivitas antioksidan ekstrak KBM terhadap DPPH secara in-vitro. Pada penelitian ini, perlakuan pengeringan terbaik didapatkan pada pengeringan suhu $30^{\circ} \mathrm{C}$. 


\section{Daftar Pustaka}

Ansori, A. N. M., Susilo, R. J. K., Hayaza, S., Winarni, D. dan Husen, S. A. (2019). Renoprotection by Garcinia mangostana L. pericarp extract in streptozotocin-induced diabetic mice. Iraqi Journal of Veterinary Sciences, 33(1): 13-19.

Beelders, T., de Beer, D., Ferreira, D., Kidd, M. dan Joubert, E. (2017). Thermal stability of the functional ingredients, glucosylated benzophenones and xanthones of honeybush (Cyclopia genistoides), in an aqueous model solution. Food Chemistry, 233: 412-421.

Beelders, T., de Beer, D., Kidd, M. dan Joubert, E. (2018). Modeling of thermal degradation kinetics of the C-glucosyl xanthone mangiferin in an aqueous model solution as a function of $\mathrm{pH}$ and temperature and protective effect of honeybush extract matrix. Food Research International, 103(August 2017): 103-109.

Chaaban, H., Ioannou, I., Chebil, L., Slimane, M., Gérardin, C., dkk. (2017). Effect of heat processing on thermal stability and antioxidant activity of six flavonoids. Journal of Food Processing and Preservation, 41(5): 1-12.

Gondokesumo, M. E., Pardjianto, B., Sumitro, S. B., Widowati, W. dan Handono, K. (2019). Xanthones analysis and antioxidant activity analysis (Applying ESR) of six different maturity levels of mangosteen rind extract (Garcinia mangostana Linn.). Pharmacognosy Journal, 11(2): 369-373.

Husni, A., Putra, D. R. dan Lelana, I. Y. B. (2014). Antioxidant activity of Padina sp. at various temperature and drying time. JPB Perikanan, 9(2): 165-173.

Irivibulkovit, K. S., Ouanthavong, S. N. dan Ameenoi, Y. S. (2018). Paper-based DPPH assay for antioxidant activity analysis, Analitical Siences, 34(July): 795-800.

Jeong, S. M., Kim, S. Y., Kim, D. R., Jo, S. C., Nam, K. C., dkk. (2004). Effect of heat treatment on the antioxidant activity of extracts from citrus peels. Journal of Agricultural and Food Chemistry, 52(11): 3389-3393.

Kim, M. Y., Lee, B. W., Lee, H. U., Lee, Y. Y., Kim, M. H., dkk. (2019). Phenolic compounds and antioxidant activity in sweet potato after heat treatment. Journal of the Science of Food and Agriculture, 99(15): 6833-6840.

Kiromah, N. Z. W., Septiani, S. W., Rahmatulloh, W. dan Aji, A. P. (2020). Penetapan parameter standar simplisia dan ekstrak etanol daun ganitri (Elaeocarpus serratus L.). PHARMACY: Jurnal Farmasi Indonesia (Pharmaceutical Journal of Indonesia), 17(1): 207.

Krisanti, E. A., Farizal, A. N. dan Mulia, K. (2021). Garcinia mangostana L. fruit rind extract in ethyl acetate, n- butanol and water fractions: phytochemical analysis, antioxidant assay and cytotoxicity assay. IOP Conference Series: Materials Science and Engineering, 1053(1): 012040.

Maliangkay, H. P. dan Rumondor, R. (2018). Uji efektifitas antidiabetes ekstrak etanol kulit buah manggis (Garcinia mangostana L) pada tikus putih (Rattus norvegicus) yang diinduksi aloksan. Chemistry Progress, 11(1).

Meilina, N. E. dan Hasanah, A. N. (2018). Aktivitas antibakteri ekstrak kulit manggis (Garcinia mangostana L.) terhadap bakteri penyebab jerawat. Jurnal Farmaka, 16(2): 322-328.

Mohammad, N. A., Abang Zaidel, D. N., Muhamad, I. I., Abdul Hamid, M., Yaakob, H. dan Mohd Jusoh, Y. M. (2019). Optimization of the antioxidant-rich xanthone extract from mangosteen (Garcinia mangostana L.) pericarp via microwave-assisted extraction. Heliyon, 5(10): e02571.

Molaei, E., Molaei, A., Abedi, F., Hayes, A. W. dan Karimi, G. (2021). Nephroprotective activity of natural products against chemical toxicants: The role of Nrf2/ARE signaling pathway. Food Science and Nutrition, (February): 3362-3384.

Ovalle-Magallanes, B., Eugenio-Pérez, D. dan Pedraza-Chaverri, J. (2017). Medicinal properties of mangosteen (Garcinia mangostana L.): A comprehensive update. Food and Chemical Toxicology, 109: 102-122.

Rohman, A., Rafi, M., Alam, G., Muchtadi, M. dan Windarsih, A. (2019). Chemical composition and antioxidant studies of underutilized part of mangosteen (Garcinia mangostana L.) fruit. Journal of Applied Pharmaceutical Science, 9(8): 47-52. 
Tousian Shandiz, H., Razavi, B. M. dan Hosseinzadeh, H. (2017). Review of Garcinia mangostana and its xanthones in metabolic syndrome and related complications. Phytotherapy Research, 31(8): 1173-1182.

Wathoni, N., Yuan Shan, C., Yi Shan, W., Rostinawati, T., Indradi, R. B., dkk. (2019). Characterization and antioxidant activity of pectin from Indonesian mangosteen (Garcinia mangostana L.) rind. Heliyon, 5(8): e02299. 